\title{
PREDICTIVE VALUE OF SEROLOGIC TESTS IN THE DIAGNOSIS AND FOLLOW-UP OF PATIENTS WITH PARACOCCIDIOIDOMYCOSIS (*)
}

\author{
Luz Elena CANO \& Angela RESTREIPO
}

\section{S U M M A R Y}

A serologic study was undertaken in a group of 43 patients with active paracoccidioidomycosis who were treated in the same form (ketoconazole), for identical periods of time ( 6 months), and followed-up for various periods posttherapy. The tests employed were agar gel immunodiffusion (AGID) and complement fixation (FC). Also studied were 50 sera from patients with proven histoplasmosis and pulmonary aspergilloma, 30 patients with culturaly proven tuberculosis as well as 92 specimens from healthy individuals, residents in the endemic area for paracoccidioidomycosis. A single lot of yeast filtrate antigen was used throughout the study. The value of each test was measured according to GALEN and GAMBINO 6. Both tests were highly sensitive, 89 and $93 \%$ respectively. Regarding their specificity, the AGID was totally specific while the CF exhibited $96.6 \%$ and $97 \%$ specificity in front of tuberculosis patients and healthy individuals respectively and $82 \%$ in comparison with patients with other mycoses. The concept of predictive value, that is, the certainty one has in accepting a positive test as diagnostic of paracoccidioidomycosis, favored the AGID procedure $(100 \%)$ over the CF test. The latter could sort out with $93 \%$ certainty a patient with paracoccidioidomycosis among a group of healthy indi. viduals and with $97.5 \%$ in the case of TB patients; when the group in question was composed by individuals with other deep mycoses, such certainty was lower (81\%). The above results indicate that both the AGID and the CF tests furnish results of high confidence; one should not relay, however, in the CF alone as a means to establish the specific diagnosis of paracoccidioidomycosis.

KEX WORDS: Predictive values; Serologic tests; Paracoccidoidomycosis; Crossreactions; Systemic mycoses.

\section{INTRODUCTION}

Paracoccidioidomycosis is a polymorphio disease and its varying clinical manifestations often delay prompt consideration by the treating physical of its real etiology. In this context serologic tests play an important role in diagnosis $1,2,11,12,17,19,25$. Furthermore and due to the chronic nature of paracoccidioidomyco. sis, such tests are also crucial in evaluating the patient's response to treatment $2,19,22,23,24$.
This being so, it would be highly desirable to attempt standardization of the various tests currently available and of the reagents employed in such tests 5,7 .

Generally, in order to achieve standardiza. tion, it is necessary to undertake the statistical analysis of the most promising tests $6,7,10$. The first step towards this goal is to evaluate the (*) Study presented during the ISHAM International Colloquium on Paracoccidioidomycosis, February 1986, Medellin, Co-
Iombia.

Corporación para Investigaciones Blológicas (CIB), Hospital Pablo Tobón Uribe, Medellin, Colombia, South America, 
CANO, I. E. \& RESTREPO, A. - Predictive value of serologic tests in the diagnosis and follow-up of patients with paracoccidioidomycosis. Rev. Inst. Med. trop. São Paulo, 29: 276-283, 1987.

tests results obtained when studying series of patients and of control individuals. We believe that various points should be emphasized here as follows:

1. The group(s) under study should be as homogeneous as possible and constituted by persons with similar characteristics. Ideally, in the case of patients - who should have been properly diagnosed - they should be active at time of first testing, be treated with the same arug and for similar periods of time, with bleedings taking place at identical periods during and after therapy. Healthy controls should be chosen among persons living in the known endemic areas for the disease under study. Patients with other fungal diseases should also be studied once their diagnosis has been properly established.

2. Identical tests should be applied to all specimens and the methods should be carefully controlled, avoiding modifica. tions to the techniques during the period of study 7,16 .

3. It would be highly desirable to use a single lot of antigen for all tests but if this is not feasible, one should employ antigens of comparable potency ${ }^{7,16}$.

The above steps would eliminate variables and would permit a more precise statistical evaluation.

During the past 6 years we have had the opportunity to perform serologic tests to a series of patients and healthy control groups who present optimal conditions for standardization. The results we obtained form the basis of this publication.

\section{MATERIAL AND METHODS}

Sera obtained from 4 groups of persons were studied, as follows:

Gnoup A: Composed by 43 patients with laboratory proven paracoccidioidomycosis as described elsewhere $21,22,24$.

Group B: Formed by 50 patients with other deep mycoses, whose diagnosis had also been established by laboratory procedures. There were 33 cases with histoplasmosis and 17 with pulmonary aspergilloma.

Group C: Constituted by 30 patients with culturally-proven tuberculosis by $\mathbf{M}$. tuberculosis var. hominis.

Group D: Composed by 92 healthy individuals, all resident in endemic areas for paracoccidioidomycosis and who had been previous. ly skin-tested with paracoccidioidin and found reactive 20 .

Concerning group A, these patients were examined at various periods. All 43 were tested at time of diagnosis, when their disease was active. They 'were all treated with ketoconazole (200 mg/day) for a period of 6 months; during this time, 42 patients were bled at month 3 of therapy and 41 at 6 months. Upon determination of therapy, 31 patients were available for testing 12 months after finishing artug intake, 16 patients after 24 and 9 after 36 - months.

Patients with paracoccidioidomycosis 'were classified as having pulmonary disease with dissemination to other organs $(29,67.5 \%)$ or as presenting involvement restricted to the lungs $(14,32.5 \%)$. Concurrent pulmonary tuberculosis was found in 5 patients (11.0\%). Regarding other parameters, most patients (42) were males and all were adults, ages 35-62 years.

Sera were collected before breakfast from all individuals (groups A, B, C, D), preserved with 1:10.000 merthiolate in buffer solution ${ }^{8}$, and kept in the refrigerator at $4^{\circ} \mathrm{C}$ until time of testing; this was done before 15 days of collection date.

The serologic tests evaluated were com. plement fixation (CF), the 50\% hemolysis micro-test recommeded by the CDC Laboratory Branch ${ }^{9}$, and the agar gel immunodiffusion technique (AGID) suggested by the Panamerican Health Organization serology study groups $^{8}$.

Both tests employed a yeast filtrate antigen obtained according to techniques already described ${ }^{23}$, from $\mathbf{P}$. brasiliensis isolate $\mathbf{B 3 3 9 .}$ A large batch was prepared and utilized all throughout the study period. 
CANO, L. E. \& RESTREPO, A. - Predictive value of serologic tests in the diagnosis and follow-up of patients with paracoccidioidomycosis. Rev. Inst. Med. trop. São Paulo, 29: 276-283, 1987.

For comparison purposes, a single lot of Histoplasma capsulatum whole yeast cells an. tigen was prepared ${ }^{15}$ and used in the CF tests.

CF results were considered positive when the titer was $\rightleftharpoons 1: 8$; IDGA results were positive when band 1 either alone or accompa. nied by bands 2 and 3 , was detected 17,18.

Statistical analysis encompassed the determination of sensitivity; especificity and predictive value as defined by GALEN and GAM. BINO' ${ }^{6}$, and KOZINN and TASCHDJIAN 10 (Table 1). The Student $t$ test was used to determine statistical significance.

T A B L E 1

Definition of terms (+)

\begin{tabular}{|c|c|c|}
\hline Concept & Definition & $\begin{array}{l}\text { Equation employed to } \\
\text { measure value of test }\end{array}$ \\
\hline \multirow[t]{2}{*}{ Sensitivity } & $\begin{array}{l}\text { Percentage of } \\
\text { disegse individuls }\end{array}$ & T.P. \\
\hline & $\begin{array}{l}\text { with positive test } \\
\text { results }\end{array}$ & T.P. + F.N. ** \\
\hline \multirow[t]{2}{*}{ Specificity } & Percentage of & T.N. **** \\
\hline & $\begin{array}{l}\text { individuals } \\
\text { with negative } \\
\text { test results. }\end{array}$ & T.N. + P. \\
\hline \multirow{2}{*}{$\begin{array}{l}\text { Predictive } \\
\text { value of a } \\
\text { positive test }\end{array}$} & Percentage of & $T . P$. \\
\hline & having disease & T.P. + F.P. **** \\
\hline
\end{tabular}

(+) Taken from Galen and Gambina" and krozinn and Taschdjian 10.

Disease present: * T. P. = true positive reactor

** F. N. = false negative reactor

*** T. N. $=$ true negative reactor

**** F. P. $=$ false positive reactor

\section{RESULTS}

Figure 1 summarizes the reactivity of the two tests employed. It can be observed that in the AGID positive results were obtained only with patients with paracoccidioidomycosis (group A), 38 (88.4\%) of whom produced precipitin lines with $P$. brasiliensis antigen. Patients with other mycoses, tuberculosis and healthy controls were non-reactive.

Concerning CF test (Fig. 1), $40(93 \%)$ of group A patients also reacted to P. brasiliensis yeast antigen; here, however, sera from other groups also proved reactive. Eight of the 33 patients with histoplasmosis (23.5\%), 1 of the 17 with aspergilloma $(5.8 \%)$ and one of the
30 TB patients (3.3\%) as well as 3 of the normal controls $(3.3 \%)$, turned out positive.

When the $\mathbf{H}$. capsulatum whole yeast cells antigen was used in the CF test (Fig. 1), all histoplasmosis sera reacted; a high proportion (37 or $86 \%$ ) of the paracoccidioidomycosis cases also recognized the heterologous antigen. Seven serum samples from aspergilloma patients $(41,0 \%)$, one of the TB patients $(3.3 \%)$ and 9 from the healthy control group (9.8\%) were also positive.

The sensitivity of both serologic tests was determined in patients with paracoccidioidomycosis, at every one of the study periods (Fig. 2). At time of diagnosis both AGID and CF proved highly sensitive ( 88 and $90 \%$ ) respectively. Therapy caused a certain loss of sensitivity with a trend towards lower figures with time of therapy. At the end of 3 years after cessation of treatment, $45 \%$ of the cases could still be detected by AGID and $85 \%$ by the CF: However, there were no statistical differences between the two tests.

The specificity was determined in the control groups (B, C and D). As can be seen in Fig. 3 the AGID test was totally specific, with no false positive reactions being recorded for patients with other mycosis, tuberculosis or healthy controls. As it pertains the CF test (Fig. 3), only 3 false positive reactions (97\% specificity) were recorded for the healthy controls, one for the TB patients $(96.6 \%)$ and 8 for the group of patients with histoplasmosis and aspergilloma (82\% specificity). The difference between healthy controls, and patients which other mycoses was statistically significant $(\mathrm{p}=<0.01)$.

Concerning the predictive value of a positive AGID test (Fig. 4), such a value was $100 \%$ both in relation to the healthy controls and to the patients with either TB or mycoses different to paracoccidioidomycosis, As for the CF test its predictive value in relation to the healthy control was high $(93 \%)$; such a value diminished during and after treatment but, it is still of $73 \%$ after 36 months of therapy cessation. In relation to the group of patients with other mycoses, the predictive value of the CF test at diagnosis was lower (81\%) than that for healthy controls (93\%) and TB pa. tients $(97.5 \%)$. After therapy, the value decreased steadely to reach $50 \%$ at 36 months posttherapy. 
CANO, L. E. \& RESTREPO, A. - 'Predictive value of serologic tests in the diagnosis and follow-up of patients with paracoccidioidomycosis. ! Zev. Inst. 'Med. trop. São Paulo, 29: 276-285, 1987.

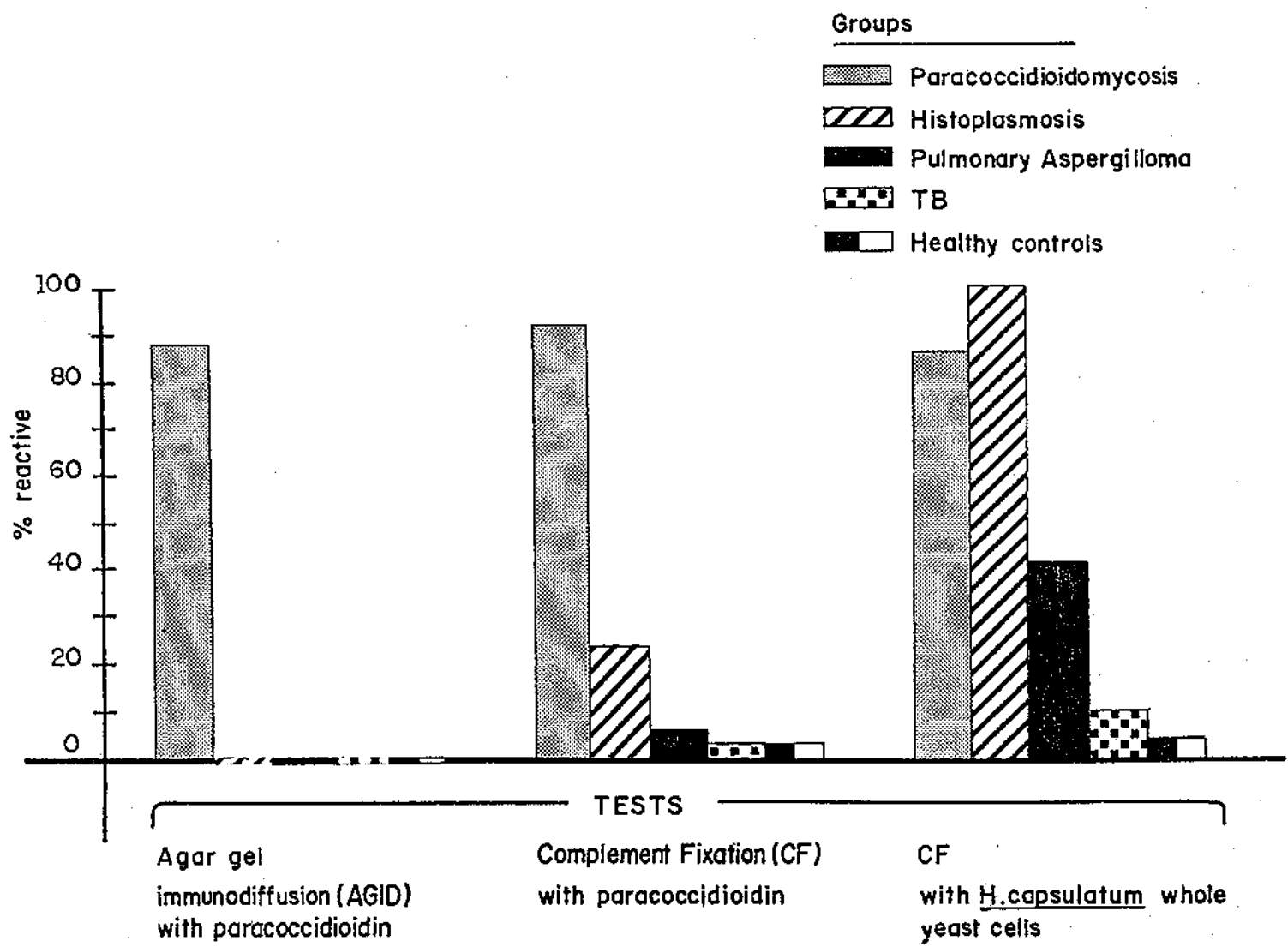

Fig. 1 - Serologic testing with P. brasilfensis and H. capsulatum antigens in patients with systemic mycoses, tuberculosis and normal persons.

\section{DISCUSSION}

The results of the present study confirm previous indications concerning the adequate sensitivity of both the AGID and the CF tests for the diagnosis of paracoccidioidomycosis $1,3,4,5,11,12,13,14,17,23,27$. Concerning the specificity of such tests, our results offer statistically supported data for the AGID, formerly shown to be highly specific $3,5,8,11,13,27$. In this regard, the CF test although highly specific (97\%) in front of healthy controls, was shown to be less precise when compared to patients with his toplasmosis and aspergilloma (82\%). These two mycotic disorders are common in the endemic areas for paracoccidioidomycosis $5,25,27$ and, in consequence, one may run into difficulties when attempting a definite diagnosis in a particular patient.

Searching for a method to clarify the above problem, we have utilized a statistical concept, that of the predictive value of a positive test and applied it to paracoccidioidomycosis. This concept advanced by GALEN and GAMBINO ${ }^{6}$, furnishes a more precise information concerning the possibility that an individual who has reacted in the test, truly has paracoccidioidomycosis. The results indicate that a serum reactive in the AGID test should come from a patient who has - or has had - par racoccidioidornycosis. The certainty comes from the $100 \%$ predictive values exhibited by this technique either at the time of diagnosis or at various periods during and after therapy. In the case of the CF test, a positive re sult in an undiagnosed patient indicates that in comparison with healthy individuals in the endemic areas, this patient has $93 \%$ possibilities of having pracoccidioidomycosis; this is also a meaningful figure. However, among a population of patients with suspected mycoses, the CF's predictive value is lower (81\%) and although not yet extremejy important, there are possibilities of misdiagnosing the patient's 
CANO, L. E. \& RESTREPO, A. - Predictive value of serologic tests in the diagnosis and follow-up of patients with paracoccidioidomycosis. Rev. Inst. Med. trop. São Paulo, 29: 276-283, 1987.

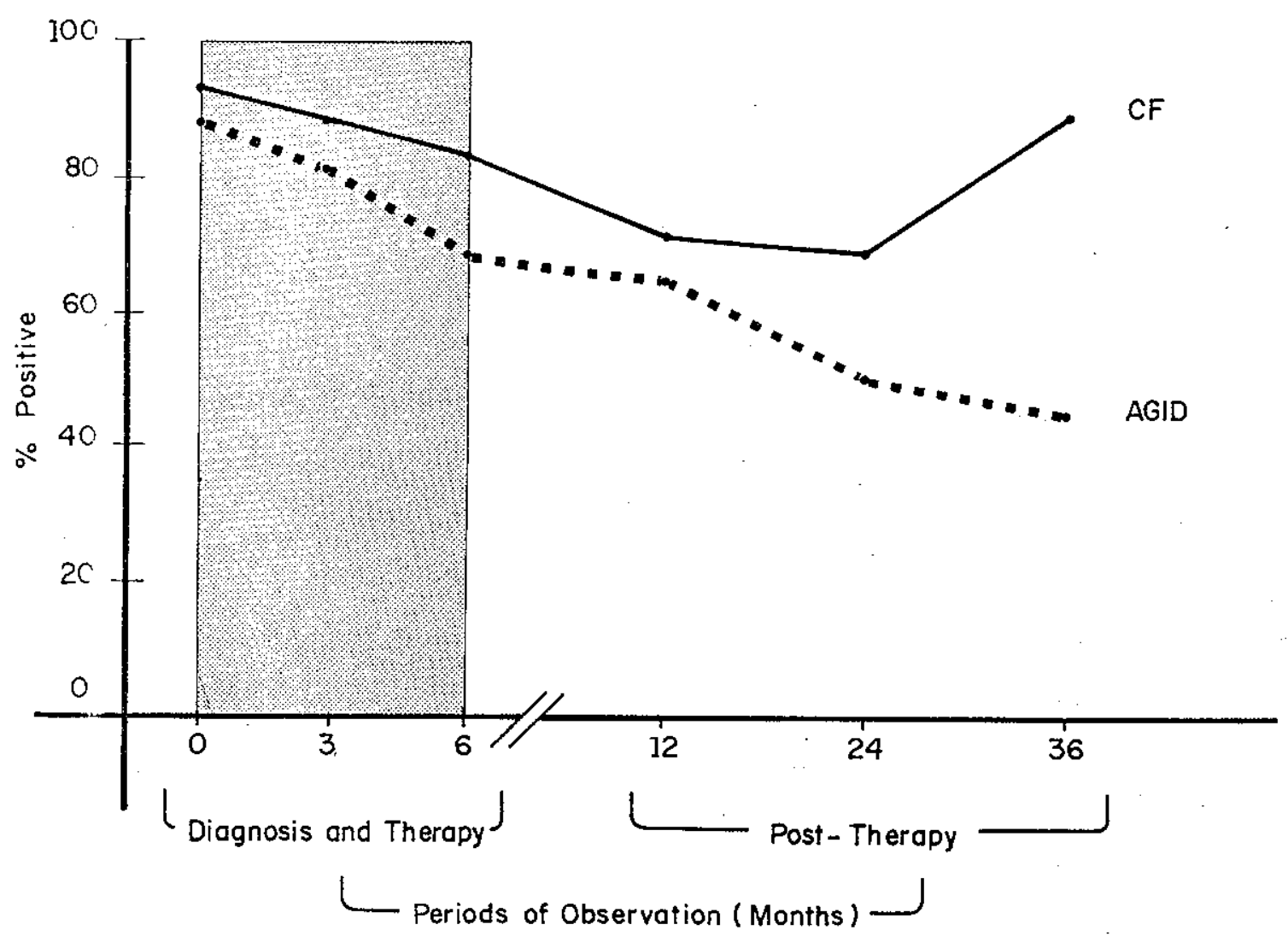

Fig. 2 - Sensitivity of serologic tests with P. brasiliensis antigens in patients with paracoccidioidomycosis before, during and after specific therapy.

illness. As it pertains tuberculosis, the predictive value was high $(92.5 \%)$, indicating that the test is capable of discriminating with high efficiency between this disorder and paracoccidioidomycosis. If treatment for the mycoses is offered, the predictive value decreases and after 36 months of therapy cessation, the possibilities of correctly determining the etiology of the past illness is only $50 \%$.

In some diagnostic centers, it has been costumary to perform both the AGID and the CF tests because the former, although much simpler to perform, does not vary extensively during the follow-up studies, while the latter procedure lends itself to adequate quantitification. The results 'we present here indicate that it is still sound to proceed along such lines.

Cross reactivity among various mycotic antigens has been extensively documented in the past $3,5,13,15,23,26,28$, with the more sensitive techniques carrying the larger burden of non. specificity $26,2 n$, Clearly. there is need to study the antigenic make up of $\mathbf{P}$. brasiliensis and of other mycotic agents causing deep-seated mycosis in order to isolate specific antigenic moities. In this form, it would be possible to produce specific antigens which would result in tests with higher predictive values and in a more precise diagnosis for the patient in need of prompt, specific therapy 5,28.

\section{RESUMEN}

Valor predictivo de las pruebas serologicas para el diagnostico $\mathrm{y}$ seguimiento de la paracoccidioidomicosis.

Con el objeto de determinar el valor predictivo de las pruebas serológicas (Fijación de Complemento, FC, e Inmunodifusión en Gel de Agar, IDGA), utilizadas regularmente en nuestro laboratorio para el diagnóstico y el seguimiento de la paracoccidioidomicosis, se 
CANO, L. E. \& RESTREPO, A. - Predictive value of serologic tests in the diagnosis and follow-up of patients with paracoccidioidomycosis. Rev. Inst. Med. trop. São Paulo, 29: 276-283, 1987.

Groups

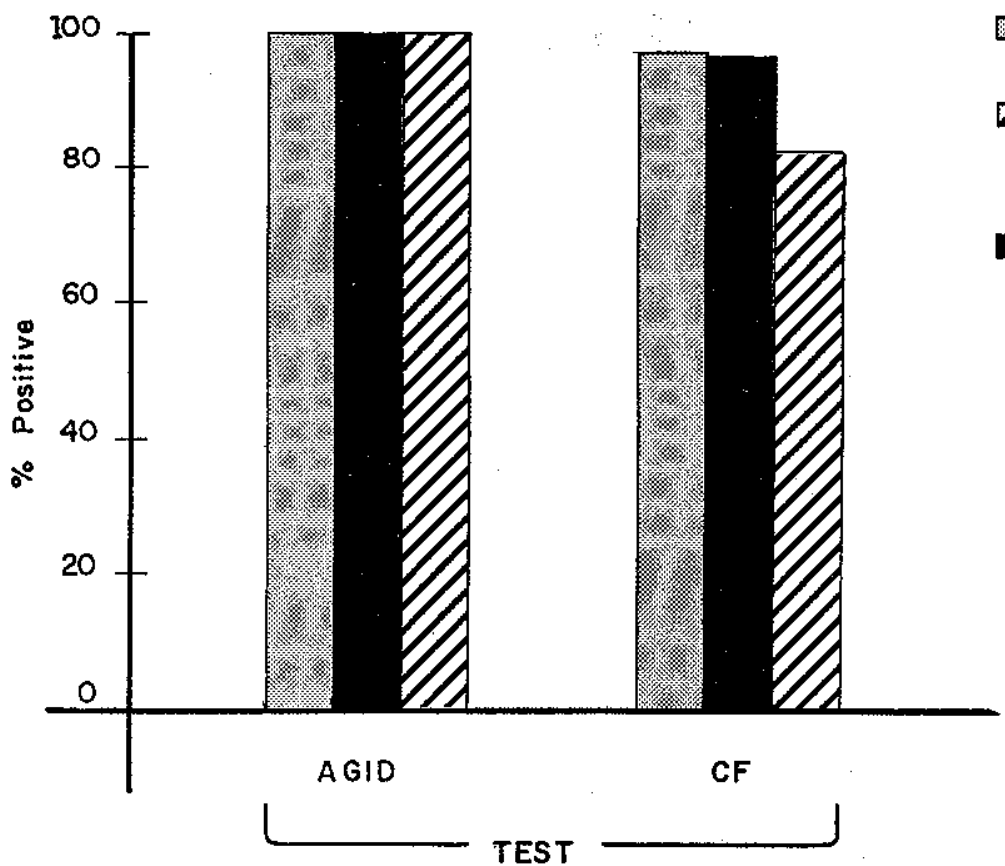

Fig. 3 - Specificity of serologic tests with $\mathbf{P}$. brasiliensis antigens in three different control groups.

Groups

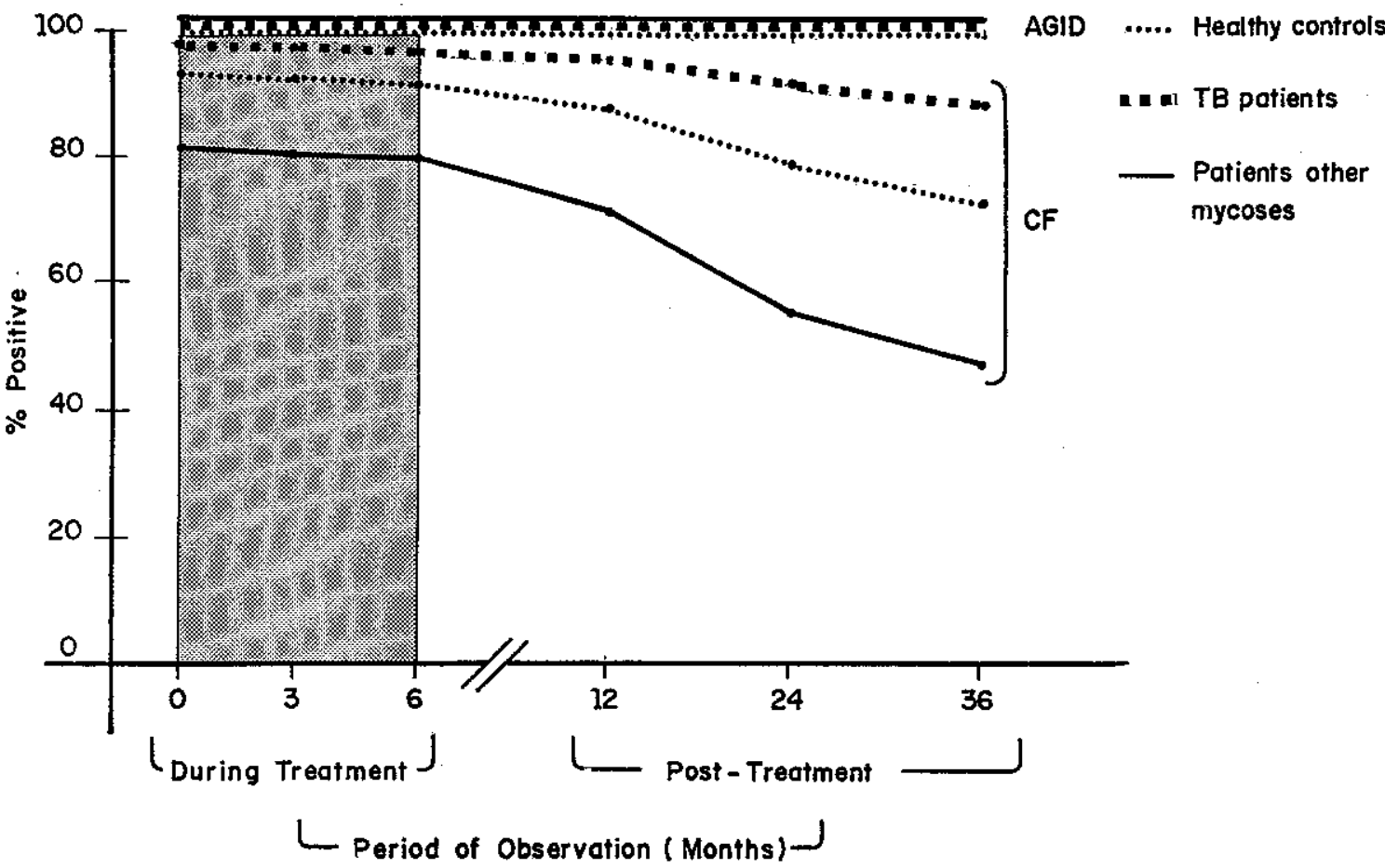

Fig. 4 - Predictive value of a pasitive serologic test in patients with paracoccidioidomycosis and in three different control groups, according to time of therapy. 
CANO, L. E: \& RESTREPO, A. - Predictive value of serologic tests in the diagnosis and follow-up of patients with paracoccidioidomycos.s. Rev. Inst. Med. trop. São Paulo, 29: 276-283, 1987.

analizaron los datos provenientes de 43 pacientes con la enfermedad. Tales pacientes fueron tratados en forma identica (Ketoconazol, 200 $\mathrm{mg} /$ dia por 6 meses); además ambas pruebas serológicas utilizaron un mismo lote de antigeno, eliminando así posibles variables. Fuera de los sueros provenientes de los 43 pacientes con paracoccidioidomicosis (A), se estudiaron 50 sueros de pacientes con atras micosis profundas (B) y 92 sueros de personas sanas (C). Empleamos las fórmulas dadas por GALEN $y$ GAMBINO 6 y hallamos que la sensibilidad de ambas pruebas serológicas era comparable, sin diferencia estadísticamente significativa entre ellas ( $\mathrm{FC}=93 \%$, IDGA $=88.4 \%$ ). Dicha sensibilidad tendía a disminuir con el tratamiento, siendo más marcada su baja durante las observaciones post-terapia. Al analizar la es. pecificidad se encontro que la IDGA era totalmente específica, no encontrandiose falsos positivos en las poblaciones controles estudiadas (B $\mathrm{y}$ C). La FC mostró un $96.7 \%$ de especificidad frente a la población $\mathrm{C}$ y un $82 \%$ frente a la B, siendo estadisticamente significativa la diferencia entre ambas. Basados en los datos anteriores, se buscó el valor predictivo, hallandose que la IDGA da seguridad completa para el diagnóstico en cualquiera de los períodos evaluados no asi la FC, la que mostró disminución de tales valores durante la terapia y la post-terapia. La curva respectiva mostró como a medida que pasaba el tiempo, disminuía la posibiildad de diferenciar la paracoccidioidomicosis (A) de otras micosis (B), manteniendose, sinembargo, la diferencia con los controles normales (C).

\section{ACKNOWLEDGEMENT}

The authors express their appreciation to the patients for their constant cooperation and to Dr. William Mejia who kindly checked the statistical analysis.

\section{REFERENCES}

1. ALBORNOZ, M. B. \& CABRAL, N. A. - Paracoccidioidomicosis. Estudio clínico e inmunológico en 40 paclentes. Arch. Kosp. Vargas (Venezuela), 18: 5-22, 1976.

2. ARCHAVALA, A.; ROBLES, A. M.; FINKELLEVICH, J. \& NEGRONI, R. - Estudio inmunológico en pacientes portadores de micosis sistêmicas $\mathrm{y}$ las modificaciones producidas por el tratamiento. Bol. Acad. Med. (B. Aires), 59: 59-73, 1981.

3. BLUMMER, S. O.; JAI.BERT, M. \& KAUFMAN, L. Rapid and reliable method for production of a specific
P. brasiliensis immunodiffusion test antigen. J. clin. Microbiol., 19: 404-407, 1984.

4. FAVA-NETTO, C. - Immunologia da paracoccidioidomicose. Rev. Inst. Med. trop. S. Paulo, 18: 42-53, 1976.

5. FGRREIRA-CRUZ, M. F.; GALVAO-CASTRO, B. \& WANKE, B. - Produção e padronizaçāo dos antfgenos de $\mathbf{P}$. braslliensis, H. capsulatum, $\mathbf{A}$. fumigatus para uso no imunodiagnóstico. Mem. Inst. Osw. Cruz, 80: $301-305,1985$.

6. GALEN, R. S. \& GAMBINO, S. R., ed. - Beyond normality. The predictive value and efficiency of medical diagnosis. New York, J. Wiley and Sons, 1975. p. 10-14.

7. HUPPERT, M.; SUN, S. H: \& VUKOVTCH, K. R. Standardization of mycological reagents. In: INTERNATIONAL CONFERENCE IN STANDARDIZATION :OF DIAGNOSTIC MATERIAL. Proceedings. Atlanta, Centers for Disease Control, 1974. p. 187-194.

8. KAUFMAN, L.; HUPPERT, M.; FAVA-NETTO, C.; NEGRONI, R. \& RESTREPO, A. - Manual of standardized serodiagnostic procedures for systemic mycosis. Part I: Agar gel immunodiffusion tests. Washington, D. C., Panamerican Health Organization, 1972.

9. KAUFMAN, L.; HUPPERT, M.; FAVA-NETTO, C.; NEGRONI, R. \& RESTREFP, A:- Manual of standardized serodiagnostic procedures for systemic mycosis. Part II: Complement fixation test. Washington, D. C., Panamerican Health Organization, 1972.

10. KOZINN, P. J. \& TASDCHJIAN, C. L. - Laboratory diagnosis of candidtasis. In: BODEY, G. P. \& FAINSTEIN, V., ed. - Candidiasis. New York, Raven Press, 1985 , p. $85-110$.

11. LONDERO, A. T.; LOPES, J. O. S.; RAMOS, C. D. \& SEVERI, L. C. A prova da dupla diffusáo em gel de agar no diagnóstico de paracocciđioidomicose: Rev. Assoc. méd. Rio Gr. Snl, 25: 272-275, 1981.

12. MARTINS-SIQUEIRA, A. - Diagnóstico imunológico. In: DEL NEGRO, G.; LACAZ, C. S. \& FTORIULO, A. M., ed. - Paracoccidioidomicose. Blastomicose sulamericana. São Paulo, Sarvier; EDUSP, 1982. p. 253-264.

13. McGOWAN, K. L. \& BUGKELY, H. R. - Preparation and use of cytoplasmic antigens for the serodiagnosis of paracoccidiodomycosis. J. clin. Microbiol., 22: 39-43, 1985

14. NEGRONI, R. - Nuevos estudios sobre antígenos para las pruebas serológicas en la blastomicosis sudamericana. Derm. Ihero lat. amer., 4: 409-461, 1968.

15. NEGRONI, R.; IOVANNITTI DE FLORES, C. \& ROBLES, A. M. - Estudio de las reacciones serologicas cruzadas entre antígenos de $\mathbf{P}$. brasiliensis y $\mathbf{f}$. capsulatum. Rev. Asoc. argent. Microbiol., 8: 68-73, 1976.

16. PALMER, D. F. \& CAVALTaRO, J. J. - Some concepts of quality control in immunoserology. In: ROSE, N. R. \& FRTEDMAN, H. ed. - Manual of clinical iminu- 
CANO, L. E. \& RESTREPO, A. - Predictive value of serologic tests in the diagnosis and follow-up of patients with paracoccidioidomycosis. Rev. Inst. Med. trop. Sāo Panlo, 29: 276-283, 1987.

nology. Washington, American Society for Microbiology, 1976 , p. $906-910$.

17. RESTREPO, A. \& MONCADA, L. H. - Serologic pro cedures in the diagnosis of paracoccidioidomycosis. In: INTERNATIONAL SYMPOSIUM ON MYCOSES. Proceedings. Washington, PAHO, 1970, p. 101-110. (Scient. Publ. No. 205).

18. RESTREPO, A. \& MONCADA, L. H. - Characterization of the precipitin bands detected in the immunodiffusion tests for paracoccidioidomycosis. Appl. Microbiol., 28: 138-144, 1974.

19. RESTREPO, A.; RESTREPO, M.; RESTREPO, F.; ARISTIZABAL, L.; MONCADA, L. H. \& VFrLEZ, H. Immune responses in paracoccidioldomycosis: a controlled study of 16 patients before and after treatment. Sabouraudia, 16: 151-163, 1977.

20. RESTREPO, A. \& CANO, L. E. - A comparison of mycelial filtrate and yeast lysate paracoccidioidin in patients with paracoccidioldomycosis. Mycopathologia (Den Haag), 84: 49-54, 1983.

21. RESTREPO, A.; GOMEZ, I.; CANO, L. E.; ARANGO, M. D.; GUTIERREZ, F.; SANIN, A. \& ROBLEDO, M. A. - Treatment of paracocciodioidomycosis with ketoconazole. A three-year experience. Amer. J. Med., 74 (1B): 48-52, 1983.

22. RESTREPO, A.; GOMEZ, I.; CANO, L, E.; ARANGO, M. D.; GUTIERREZ, F.; SANIN, A. \& ROBLEDO, M.
A. - Post-therapy status of paracoccidioidomycosis patients treated with ketoconazole. Amer. J. Med., 44 (1B): $53-57,1983$

23. RESTREPO, A. - Procedimientos serológicos en la paracoccidioidomicosis. Adelantos Microbiol. Enferm. Infec. 3: 183-211, 1984

24. ROBLEDO, M. A.; GOMEZ, I.; GUTIERREZ, F.; CANO. L. E. \& RESTREPO, A. - Ełvaluación a largo plazo de pacientes. con paracoccidioidomicosis tratados con ketoconazol. Acta med. colomb.; 10: 155-160, 1985.

25. RUBINSTEIN, P. \& NEGRONI, R., ed. - Micosis broncopulmonares del adulto $y$ del nifío. Buenos Aires, Editorial Beta, 1981. p. 126-150; 193-221.

26. WHEAT, J.; FRENCH, M. L. V.; KAMFL, S. \& TEWARI, R. P. Evaluation of cross-reactions in $\mathbf{A}$. capsulatum serologic tests. J. clin. Microbiol., 23: 493$499,1986$.

27. YARZABAL, L. A.; ALBORNOZ, M.; CABRAL, N. H; SANTIAGO, A. R. - Specific double diffussion micro technique for the diagnosis of aspergillosis and paracoccidioidomycosis using monospecifle antisera. Sabou. raudia, 16: 55-62, 1978.

28. YARZABAL, L. - Composìción antigénica de P. bra. siliensis. In: DEL NEGRO, G.; LACAZ, C. S. \& FIORILLO, A. M., ed. - Paracoccldioidomicose. Blastomicose sul-americana. Săo Paulo, Sarvier; HDUSP, 1982. p. $59-67$.

Recebido para publicação em 21/7/86. 